\title{
Yunus Emre Kimdir? Bizim Yunus’un Sevgi ve Hoşgörü Anlayışının Posta Pulları Üzerinden Değerlendirilmesi
}

\author{
Who is Yunus Emre? Evaluation of our Yunus' Understanding of Love and \\ Tolerance on Postage Stamps
}

\author{
Serkan AYCIL (iD)
}

\begin{abstract}
$\ddot{O} \mathbf{z}$
Orta Asya'da yaşayan Türkmenlerin çoğu Moğol istilasından sonra, güvenli liman olarak gördükleri Anadolu'ya göç ettiler. Bu dönemde Anadolu'da yaşayan Müslüman Türkler ile Orta Asya'dan gelen Türkmenler arasında önemli derecede dini ve kültürel farklılıklar bulunmaktaydı. Yerleşik hayata geçen Müslüman Türkler, daha gelenekçi bir yapıya sahipken, Orta Asya'dan gelen Türkmenler ise Şamanizm'in etkisi altında yarı göçebe bir zihniyetle yaşıyorlardı. Demografik ve siyasi değişime, ekonomik sıkıntılar eşlik edince, huzur ortamı bozuldu ve olası bir çatışma kaçınılmaz oldu. Tüm kaynaklarını seferber eden Anadolu Selçuklu Devleti, Baba İlyas ve Baba İshak çevresinde toplanan Türkmen grupların isyanını güçlükle bastırdı. Gücünün tamamını tüketen otorite, bir daha eski formunu yakalayamadı. Ortaya çıkan otorite boşluğu ise huzursuz ve güvensiz bir ortama zemin hazırladı. Eski cazibesini yitiren Anadolu, bundan sonraki süreçte, bir birbiriyle rekabet eden toplumlara ev sahipliği yaptı. 13. ila 14. yüzyıllarda yaşamış olan Yunus Emre yaşanan bu istikrarsızlık karşısında bütün halkı sevgiye ve hoşgörüye davet etti. Kısa sürede ekole dönüşen bu hareket Anadolu'nun dokusunu değiştirdi ve Yunus Emre'yi gönüllerin odağına taşıdı. Bütün bu bilgilerden hareketle çalışmanın amacı; Yunus Emre'nin sevgi ve hoşgörü anlayışını, posta pulları üzerinden farklı bir formda kurgulamaya çalışmaktır. $\mathrm{Bu}$ çalışmada Yunus Emre'nin yaşam felsefesini oluşturan; insan faktörü, Türk dili vurgusu, dünya yaşantısı, terkler, gönül güzelliği, sevgi ve hoşgörü konularına da yer verilmiştir. Çalışmada toplam 10 adet görsel kullanılmıştır. Bu görsellerin 9'u pullardan 1'i ise özelgün zarfindan oluşmaktadır. Çalışmanın, bilimsel nitelikli araştırmalara kaynak teşkil edeceği düşünülmektedir.
\end{abstract}

Anahtar Kelimeler: Yunus Emre, sevgi ve hoşgörü, posta pulu, pul, terkler

Makale Türü: Araştırma

\begin{abstract}
Most of the Turkmen living in Central Asia migrated to Anatolia, which they saw as a safe haven, after the Mongol invasion. In this period, there were significant religious and cultural differences between the Muslim Turks living in Anatolia and the Turkmens coming from Central Asia. While the settled Muslim Turks had a more traditional structure, the Turkmens from Central Asia lived with a semi-nomadic mentality under the influence of Shamanism. When the demographic and political change was accompanied by economic troubles, the atmosphere of peace deteriorated and a possible conflict became inevitable. The Anatolian Seljuk State, which mobilized all its resources, suppressed the rebellion of the Turkmen groups gathered around Baba İlyas and Baba İshak with difficulty. Having exhausted all its power, the authority never regained its former form. The resulting vacuum of authority paved the way for an uneasy and insecure environment. Losing its old charm, Anatolia hosted societies that competed with each other in the next period. Yunus Emre, who lived in the 13th and 14th centuries, invited all the people to love and tolerance in the face of this instability. This movement, which turned into a school in a short time, completely changed the texture of Anatolia and brought Yunus Emre to the center of hearts. Based on all this information, the aim of the study is; Trying to reinterpret Yunus Emre's understanding of love
\end{abstract}

\footnotetext{
${ }^{1}$ İstanbul PTT Bölge Başmüdürlüğü, Muhasebe ve Finans Müdürlüğü, sserkan.aycil @ mail.com
} 
and tolerance through postage stamps. In this study, Yunus Emre's philosophy of life; human factor, emphasis on Turkish language, world life, abandonment, beauty of heart, love and tolerance. A total of 10 images were used in the study. 9 of these images consist of stamps and 1 of them consists of a special day envelope. It is thought that the study will be a source for scientific researches.

Keywords: Yunus Emre, love and tolerance, postage stamp, stamp, abandonments

Paper Type: Research

\section{Giriş}

Anadolu Selçuklu Devletinin ilk zamanları genellikle Haçlı Seferlerinin bertaraf edilmesiyle geçmekteydi. Hali hazırda bu karışıklığa henüz bir çözüm bulunamamışken Orta Asya'da Moğol istilası patlak verdi. Cengiz Han'ın ordusu, ayrım yapmaksızın girdiği bütün şehirleri yaktı ve buralarda yaşayan herkesi yok etmeye çalıştı. Yaşanan korku ve şiddet olayları Orta Asya'da yaşayan halkları daha güvenli bölgelere göç etmeye zorladı. Dolayısıyla güvenli liman olarak görülen Anadolu, bu dönemde kapasitesinin çok üzerinde bir göç akınıyla karşı karşıya kaldı. Orta Asya'dan gelen Türkmen toplumlar ile Anadolu'da yaşayan Türkler arasında ciddi manada dini ve kültürel farklılıklar bulunmaktaydı (Yıldırım, 2012, s. 14). Anadolu'da yaşayan Türkler İslamiyet'in kural ve kaidelerini tamamen benimsemiş ve yerleşik yaşama geçmişlerdi. Bu nedenle Türkler arasında daha gelenekçi bir yapı hâkimdi. Orta Asya'dan gelen Türkmenler ise göçebe veya yarı göçebe bir kültürün etrafında günlük faaliyetlerini idame ettirmeye çalışıyorlardı. Ayrıca Türkmenlerin inanç sistemi de Şamanizm'in ekseninde şekillenmişti. Bu nedenle tarım, üretim, ticaret ve yaylak-kışlak kültürü bu toplumlar için çok uzak kavramlardı. Dini ve kültürel yaşamdaki bu tür farklılıklar, en sonunda her iki toplumun tahammül sınırını zorladı ve olası bir savaş artık kaçınılmaz oldu (Ekici, 2005, s. 96-97). Bunun üzerine Türkmen gruplar Baba İshak ve Baba İlyas'ın önderliğinde bir araya gelerek Anadolu Selçuklu Devletine karşı savaş açtılar. Ayaklanma ve isyan özelliği taşıyan bu harekâtı Anadolu Selçuklu Devleti güçlükle bastırdı. Savaş sonunda, isyancı konumunda olan Türkmenlerin tamamı, muharebe alanında yok edildi. Görünürde bir zafer nidası olarak görülen bu savaş, uzun vadede çözümü bulunamayan birçok soruna zemin hazırladı. Çünkü bu harekât Anadolu Selçuklu Devleti için bir kırılma noktasıydı. Dolayısıyla mevcut kaynakların neredeyse tamamı bu isyanların bastırılabilmesi için seferber edilmişti. Bu savaş dini, siyasi, kültürel ve ekonomik yetkinliğin yanı sıra iktidar mücadelesini de kapsayan bir sürece işaret ettiği için toplum nezdindeki etkileri de tahmin edildiğinden çok daha uzun bir süreci kapsadı. Savaş sonunda hem devlet yönetimi hem de halk, karanlık bir sürece girdi (Keleş, 2018, s. 89-90).

Baycu Noyan komutasındaki Moğol ordusu Anadolu'nun içlerine doğru ilerlerken uğradığı her yerleşim alanını yakıp yıkmaya başladı. 1243 yılında Anadolu Selçuklu Devletiyle Moğol ordusu ilk kez karşı karşıya geldi. Yapılan savaş sonunda, ağır bir yenilgi alan Anadolu Selçuklu Devleti Kösedağ Savaşı sonrası yapılan barış anlaşmasını kabul etmek mecburiyetinde kaldı. Anlaşma ağır yaptırımlar içeriyordu (Koca, 2015, s. 64-67). Müzakereyi onaylayan Anadolu Selçuklu Devleti artık bu tarihten sonra Moğollara bağlı bir bölge olarak kalmayı kabul etmiş oldu. 1256 yılında yapılan direnme savaşında, ikinci bir yenilgi daha alındı ve Anadolu Selçuklu Devleti artık işlevsiz bir devlet haline geldi (Yıldırım, 2012, s. 15). Oluşan otorite boşluğu ise Anadolu'daki beylikler tarafından doldurulmaya çalışıldı. Bundan sonraki süreç, tarihi kayıtlara 2. Anadolu Beylikleri Dönemi olarak geçti.

Yunus Emre'nin yaşadığı dönemde Anadolu'da siyasi istikrar bozulmuştu. Moğol istilasının etkisinde kalan halk zor günler yaşamaktaydı. Siyasi çekişmelerin yanı sıra kuraklık ve kıtllk gibi doğal bileşenlerde gerginliğin büyümesine kaynak teşkil etmekteydi. Bu denli sıkıntılı bir süreçte Allah (cc) sevgisini, dini inançları ve ahlaki değerleri Türk-İslâm sentezi çerçevesinde teşekkül etmeye çalışan Yunus Emre özgün bir medeni birikimin oluşmasında etkin bir rol oynadı. Bu nedenle onun şiirleri halk nezdinde kabul gördü ve kısa zamanda Anadolu'nun her köşesine yayıldı. Çünkü onun umut vadeden şiirleri, topluma maneviyat aş111yor ve toplumu yeniden şekillendiriyordu. 


\section{Araştırmanın Amacı ve Önemi}

$\mathrm{Bu}$ araştırmanın amacı Yunus Emre'nin sevgi ve hoşgörü anlayışını, posta pulları üzerinden farklı bir formda kurgulamaya çalışmaktır. Yunus Emre'nin hayatını, şiirlerini, edebi kişiliğini ve tasavvufi yönünü ele alan diğer araştırmalarının neredeyse hiç birinde, görsel kullanımlara yer verilmemiş̧ir. Literatür boyutunu görsel nesnelerle destekleyen bu çalışmada Yunus Emre olgusu, farklı bir perspektiften ele alınmıştır. Literatüre farklı bir boyut getirmesi açısından bu araştırmanın önemli bir çalışma olduğu düşünülmektedir.

\section{Yöntem}

Nitel araştırma yaklaşımı üzerinden oluşturulan bu çalışmada doküman analizi yöntemi kullanılmıştır. Doküman analizi, araştırılan konuyla ilintili olan belgelerin, sistematik olarak incelenmesini öngören bir çalışma türüdür. Dolayısıyla ilk etapta, hedeflenen olguyla ilgili bilgileri içeren yazılı kaynaklar incelenir. Akabinde; görüntü kaydı, sesli video, belgesel, film ve fotoğraf gibi görsellerin incelenmesiyle elde edilen veriler üzerinden, anlamsal çıkarımda bulunulur. $\mathrm{Bu}$ araştırma yöntemi, bilgiye erişimde zamansal avantaj sağlarken araştırma maliyetini de oldukça aşağı seviyelere çekmektedir (Merriam, 2013, s. 13; Wach ve Ward, 2013, s. 1; Yıldırım ve Şimşek, 2008, s. 39).

Doküman analizi ve görsel araştırma üzerinden kurgulanan bu çalışmada iki farklı araştırma yöntemi kullanılmıştır. Doküman analizi; kitap, ansiklopedi, tez arşivi, gazete, dergi, rapor, basılı eser ve dijital yayınlar gibi yazılı kaynaklar üzerinden alınan veriler aracılı̆̆ıyla gerçekleşmiştir. Görsel incelemede ise Yunus Emre'yi sevgi ve hoşgörü olgusu üzerinden literatür boyutuna taşımayı amaçlayan bir içerik oluşturulmaya çalışılmıştır. Bu nedenle konuyla ilişkili pul nesneleri ve özelgün zarfları tedarik edilmiş ve bu çerçevede konu bütünlügü oluşturulmaya çalışılmıştır.

Çalışmada toplam 10 adet görsel kullanılmıştır. Bu görsellerin 9'u pullardan 1'i ise özelgün zarfından oluşmaktadır. Yunus Emre ile direkt ilintili olan toplam 8 pul bulunmaktadır. 1 pulda ise martı görseline yer verilmiştir. Ayrıca pulların 3'ü kișisel pul özelliğine sahip olup farklı kurumlar tarafından bastırılmıştır. Şekil 1.'de Yunus Emre'nin Ölümünün 650. Yllı anısına bastırılan bir tasarıma yer verilmiştir. 1971 yılında, 400.000 adet olarak bastırılan bu pulların grafik tasarımını Profesör Namık Bıyık üstlenmiştir. Sağ profilden bakan Yunus Emre bu görselde kirli sakallı, zayıf ve takkeli olarak resmedilmiştir. Şekil 2.'de Mihalıççık Belediyesinin Yunus Emre ve Türkçe Yllı anısına bastırdığı kişisel pul resmedilmiştir. Başına börk takan ve sağ elinde saz tutan Yunus Emre bu tasarımda sade kıyafetli, orta boylu, sakalsız ve bıyıklı tasvir edilmiştir. Şekil 3.'de 2021 yılında tedavüle çıkarılan ve sadece 2.500 adet bastırılan özelgün zarfı yer almaktadır. Bu görseldeki Yunus Emre diğer resimlerin aksine sol profilden resmedilmiştir. Başında börk bulunan ve sakalsız olan Yunus Emre bu görselde bıyıklıdır. Tarih damgasında silueti beliren Yunus Emre'nin sırtında heybesi, sağ elinde ise asası bulunmaktadır. Şekil 4. ve Şekil 5.'de yer alan görseller Yunus Emre'nin Vefatının 700. Yılı anısına Karaman Belediyesi tarafından bastırılan tasarımlardan oluşmaktadır. Mevcut tasarımlarda 2 farklı şablon kullanılmıștır. Belirgin yüz hatlarına sahip olan Yunus Emre bu tasarımda sağ profilden resmedilmiştir. Başında börk bulunan Yunus Emre bu görselde sakalsız ve biyıklıdır. Ayrıca tasarımlarda hem UNESCO'nun hem de Karaman Belediyesinin logosuna yer verilmiştir. Şekil 6.'da 2010 yılında tedavüle çıkarılan ve 2 ayrı tasarımdan oluşan pullardan 1.'sine yer verilmiştir. Ofset baskı tekniğiyle oluşturulan bu pulların grafik tasarımını Bülent Ateş yapmıştır. Basım adedi 250.000 olan bu pullara ek olarak bir de ilkgün zarfi ilave edilmiştir. Sol profilden resmedilen pulun cari değeri 0.90 kuruştur. Tasarımın arka planında ise Anadolu'nun çatlamış toprakları yer almaktadır. Yunus Emre'den bir beyite de yer verilen tasarımda, sevgiye davet teması ve kırmızı kalp simgesi kullanılmıştır. Börk takan Yunus Emre bu tasarımda sakalsız ve bıyıklıdır. Şekil 7. ve Şekil 8.'de 1991 yılında tedavüle çıkarılan ve 2 ayrı tasarımdan oluşan pullara yer verilmiştir. Bu pullar 1991 Yunus Emre Sevgi Yılı anısına bastırılmıştır. Baskı adedi 300.000 olan bu pulların grafik tasarımcısı Hidayet Aksu'dur. 
Tasarımlardan ilki 1.500+100 ETL değerindedir. 1. görselde Yunus Emre ağaç olarak tasvir edilmiştir. Tasarımdaki sevgi ağacının, küçük kalpler biçiminde meyveler verdiği görülmektedir. İkinci tasarım ise geometrik imge ve semboller üzerinden betimlenmiştir. Sağ profilden resmedilen ve börk takan Yunus Emre bu tasarımda çok renkli ve sakallıdır. Şekil 9.'da 2021 yılında tedavüle çıkarılan ve sadece 2.500 adet bastırılan özelgün zarfındaki pul görseline yer verilmiştir. Hoşgörü ve sevgi temasını ön plana çıkaran bu tasarım, ağzında gül taşıyan bir martının süzülüşüne sahne olmaktadır. Şekil 10.'da ise 2010 yılında tedavüle çıkarılan ve 2 ayrı tasarımdan oluşan pullardan 2.'si resmedilmiştir. Bu tasarımda Yunus Emre'nin sevgiye davet ve hoşgörü anlayışı ön plana çıkmaktadır. Diğer tasarımlardan farklı olan bu çalışmada Yunus Emre'nin Mihalıççık'ta bulunan ve 1974 yılında ziyarete açılan anıt mezarı yer almaktadır.

\section{Yunus Emre Hakkında Pul Nesneleri ve Özelgün Zarfları}

Türkmen dervişi olan Yunus Emre 13. ila 14. yüzyıllarda Orta Anadolu'da yaşamış önemli bir şahsiyettir. Mihalıççı'a bağlı Sarıköy'de doğan Yunus Emre Horasandan Anadolu'ya gelen bir aileye mensuptur. Zaman içerisinde şeyhlik mertebesine erişen Yunus Emre, kurduğu zaviyelerle düşüncelerini aktarma imkânı bulmuştur. Yaşadığı dönemin önemli şahsiyetleri arasında yer alan Hacı Bektaş Veli'nin sohbetlerine dâhil olmuş ve ondan gerekli ilimleri tahsil etmiştir. Sonraki zamanlarda ise Hacı Bektaş Veli'nin yönlendirmesiyle Taptuk Baba'ya giderek uzun yıllar hizmetinde bulunmuştur (Kaplan, 2018, s. 157). Tekkede bulunduğu süre içerisinde olgunluk mertebesine eriştiğini vurgulayan Yunus Emre duyduğu vefa nedeniyle hocası Taptuk Emre'ye şiirlerinde sıklıkla yer vermiştir. Aşağıda yer alan beyitte konuya dair bir çıkarımda bulunulmuştur.

\section{Taptuğun tapusunda, kul olduk kapusunda}

Yunus miskin çiğ idik, piştik elhamdülillâh (Toprak, 2006, s. 143).

Yunus Emre'nin şiirlerinde; insan sevgisi, hoşgörü, iyilik, adalet, doğruluk, sabır, cömertlik, güzel söz söyleme, mütevazılık, bilgelik, kötü sözden kaçınma, dünya malından uzak durma ve tamahkâr olmama gibi değerler ön plana çıkmaktadır. Ancak, onun şiirlerinde üzerinde durduğu en temel olgu kuşkusuz insan sevgisi ve hoşgörüdür. O toplumdaki sevgi eksikliğini hissettiği için de şiirlerinde aşk kavramına sıklıkla yer vermiştir. Çağlar ötesini aşan öğretileriyle birçok mutasavvıfa ve şaire ilham kaynağ 1 olan Yunus Emre şiirlerinde daha çok dini ve insani olgular üzerinde durmuştur. Şiirlerinde, şahıslara yönelik söylemler geliştirdiği algısı oluşmuş olsa da aslında, o insanların refahı ve mutluluğu için bireyde bulunması gereken nitelikleri dervişler üzerinden genelleyerek sunmaya çalışmaktadır (Benazus, 2021, s. 56; Koç ve Tanhan, 2010, s. 631-632). Nihayetsiz bir hoşgörü anlayışına sahip olan ve her şeyi Allah (cc) sevgisi üzerine kurgulayan Yunus Emre, iyiliğin ve doğruluğun yegâne temsilcisi konumundadir.

Şekil 1. Yunus Emre

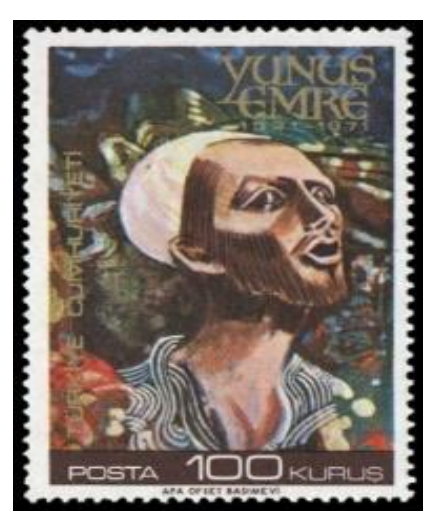

Kaynak: Güven Bezaz, 2006: 323. 


\section{Yunus Emre’ye Göre İnsanın Amacı}

Yunus Emre'ye göre, insanın dünya geliş amac1, sahip olduğu kibri ve gururu kırmaktır. $\mathrm{O}$ dünyayı aldatıcı olarak betimler. Bu nedenle fani olan hiç bir şeyin arkasından gidilmemelidir (Pür, 2021, s. 23). Çünkü geçici olan bir şeyi amaç edinenlerde hırs ortaya çıkmaktadır. Hırs ise insanı bağımlı hale getirerek, insan-1 kâmil mertebesine ulaşmaktan men etmektedir. Aşağıda yer verilen beyitte bu duruma dair çıkarımda bulunulmuştur.

Bak göresin dünyeye geldügüni bil neye

İş bu fânî dünyeye magrûr olmamagiçün (Tatc1, 1997, s. 251).

İnsanın yaradılışındaki bir diğer hikmet ise sevmek, sevilmek ve dostluğun farkına varmaktır. Aksine nefret etmek, düşmanlık gütmek, kin beslemek ve kavga etmek ise yaradılışın tabiatına aykırı davranışlardır (Sevgi, 2001, s. 101).

\section{Yunus Emre ve Türk Dili Üzerine}

Yunus Emre'nin döneminde yaşayan edebi şahsiyetler, farsça eserler üretmekteydi. Türkçeye hâkim olan ve Türkçeyi iyi derecede kullanan Yunus Emre, tasavvufa dair manaları Türkçeleştirerek farklı bir formda sunmuştur. Onun bu tavrı sayesinde Türk dili zenginleşerek derinlik kazanmıştır. Edebi açıdan Ahmed-i Yesevi'den ziyadesiyle etkilenen Yunus Emre Ahmed-i Yesevi'nin şiirlerinden bazılarına nazireler yazmıştır. Bu yaklaşım Yunus Emre'nin Anadolu'daki nazire edebiyatının ilk temsilcisi olarak anılmasında da etken olmuştur (Yavuz, 2017, s. 28). Ancak, konuya farklı bir boyut getiren bazı araştırmacılar Yunus Emre'nin ümmi olduğunu beyan etmektedir.

Şiirlerinde oldukça akıcı bir dil kullanan Yunus Emre, tasavvufun en zor konularını dahi yalın bir üslupla anlatabilmiştir (Benazus, 2021, s. 54-55). Milli unsurları tasavvufla bir araya getiren Yunus Emre, farklı formda kurguladığı tekke edebiyatını özgün bir yapılanmayla yeniden yorumlamıştır. Onun bu denli sevilmesinin belki de en önemli nedenlerinden biri de kullandığ 1 üsluptur. Şiirlerinde tasavvufi konulara sıkça yer vermesi, duygu ve düşüncelerini aktarmada şiiri basamak olarak kullandığını göstermektedir (Kaplan, 2018, s. 158). Tasavvufu ve bilgiyi sade bir Türkçeyle şiirlerinde işleyen Yunus Emre, bu sayede çağları aşan bir üne kavuşmuştur. Onun şiirleri, kendi düşüncelerinin yanı sıra ulusal kültüre dair değerleri de içeren ortak bir payda oluşturma çabasındadır.

Yaşadığı dönemde Yunus Emre'nin hedef kitlesini daha çok Türkçe bilen konargöçerler oluşturmaktadır. Bu gerçeklik, tercihten ziyade zorunluluğa dayanan bir olgudur. Çünkü Yunus Emre Ahmet Yesevi'yi örnek almış olan Taptuk Baba gibi yaşamayı tercih etmiştir. Taptuk Babanın halk nezdindeki ilişkisi ise göçebe kültür üzerinden şekillenmiştir (Ocaktan aktaran Kaval, 2013, s. 105).

Yunus Emre'nin vefatının 700. yılına denk gelen 2021 yılı UNESCO tarafindan, anma ve kutlama yıl dönümleri programına dâhil edildi. Türkiye Cumhuriyeti'nin aldığı kararda ise 2021 yılı Yunus Emre ve Türkçe yll olarak ilan edildi. Anma etkinliğine farklılık ekleyen Mihalıççık Belediyesi Yunus Emre başta olmak üzere Taptuk Emre, Hac1 Bektaş Veli ve Ahi Evran temalı 8 farklı görselden oluşan pul serisi bastırdı. Mihalıççık Belediyesinin bastırdığ Yunus Emre temalı örnek pul tasarımı Şekil 2'de gösterilmiştir. 
Şekil 2. 2021 Yunus Emre ve Türkçe Yılı konulu tasarım, Mihalıççık Belediyesi, Eskişehir

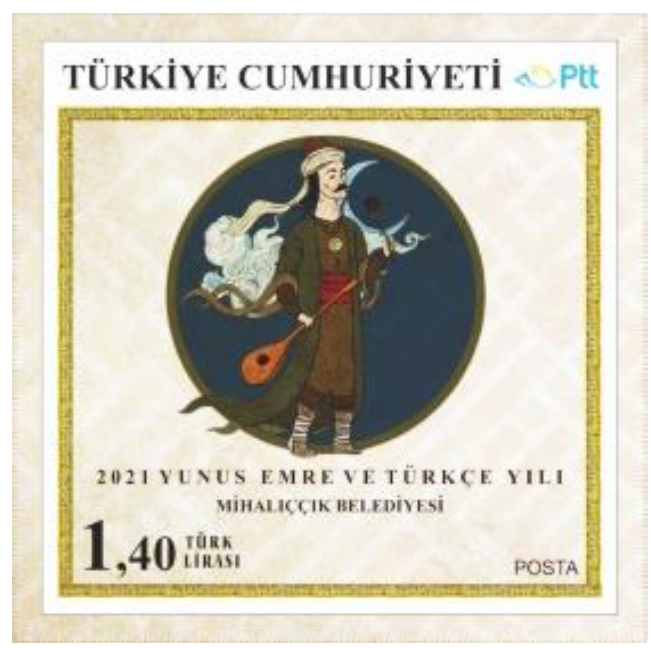

Kaynak: URL-1

Şekil 3. 2021 Yunus Emre ve Türkçe Y11ı konulu özelgün zarfı

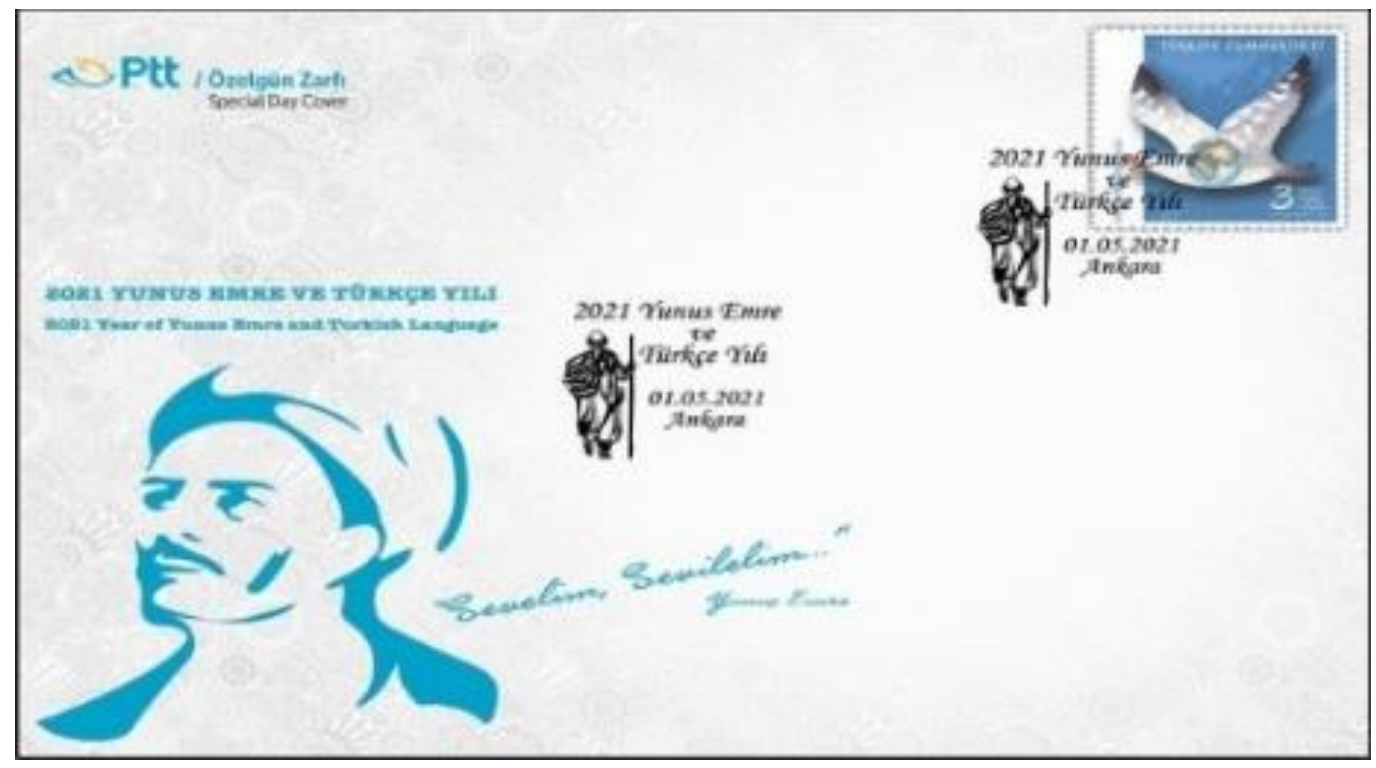

Kaynak: Araştırmacının arşivinden taratılarak elde edilmiştir.

\section{Yunus Emre'nin Dünya Anlayıșı ve Terkler Üzerine}

Yunus Emre insanın iki yönünün olduğunu söyler. Birinci yönü, ilahi ve uhrevi olarak tarif ederken, ikinci yönü maddeye dönük dünyasal olarak betimler. Bu nedenle aşkın, insanı iyiye yönelterek Allah'a (cc) yakınlaştırdığını vurgular. Ona göre aşk ve sevgi bütün iyiliklerin kaynağını oluşturmaktadır (Benazus, 2021, s. 57). Yunus Emre dünyanın faniliğine değindiği bir beyitte, dargınlığın ve küskünlüğün önemsenmeyecek bir durum olduğuna, asli olanın ise insanın sevgi ve birlik düsturuyla bir arada yaşaması olduğuna vurgu yapılmıştır (Pür, 2021: 22).

Bu dünyâya kalmayalum fânîdür aldanmayalum

Bir iken ayrılmayalum gel dosta gidelüm gönül (Tatc1, 1997, s. 160). 
Yunus Emre, tasavvuf yolunu benimsemiş önemli bir şahsiyettir. Tasavvufun en temel değerleri ise terkler üzerine kuruludur. Allah'ın (cc) sevgisine erişebilmek için Allah (cc) yolunda bütün değerlerin feda edilmesi gerekmektedir. İtibar, huzur, servet, rahatllk ve şöhret gibi olgular, her zaman, ulvi değerlerin önünde tenteneli bir perde olarak düşünülmüştür. Hatta tasavvufun ileri boyutunda, dünyadaki değerlerin yanı sıra öteki âlemlerdeki değerlerin terkinin gerekliliği de ortaya çıkmaktadır (Ülken, 2001, s. 337). Bu realite terk-i terk kavramıyla açıklanmaktadır. Bu açıdan bakıldığında terk kavramı, hakiki sevgiye muhatap olabilmenin en somut anlatımı olarak ortaya çıkmaktadır. Allah (cc) insanı, mükemmel bir sistem ekseninde halk etmiştir. Bu sistemdeki mükemmel işleyiş ise ancak aracısız bir iletişimle mümkün hale gelebilmektedir. Hayatı boyunca İnsanın karşısına çıkan her bir dünyevi bağlılık, bu iletişim ağında oluşan bir parazite karşılık gelmektedir. Dolayısıyla her bir dünyevi değerin terki, şeffaf ve dolaysız bir iletişim için ortadan kalkan bir engeli temsil etmektedir. Bir diğer husus ise şöyledir: Hz. Âdem yaratılmadan önce İblis, meleklerin hocası olarak vazife görmekteydi. Yeryüzünün her karıșında secde eden İblis'in bu vazifesi, beșeriyet üzerine secdeye inmemesiyle son bulmuştur. Meleklerin hocası olması münasebetiyle de her türlü ilimden nasibini ziyadesiyle almıştır. Dolayısıyla insanın ilim yoluyla İblis'e üstün gelmesi mümkün değildir. Bu nedenle İblis'in ancak İblis'te olmayan bir özellikle bloke edilmesi gerekmektedir. $\mathrm{Bu}$ ulvi değer ise terktir. Çünkü İblis'in sisteminde bulunan her şey yok kavramı üzerine kurulmuştur. Mevcut sistemi menfi yönde kullanan İblis, her ulvi değeri yok etme çabasındadır. $\mathrm{Bu}$ süreçte de vesvese hastalığını kullanmaktadır. Buna göre İblis, var olan her değerin karşısına yok olanın karşılığ 1 getirilmektedir. Yani müspetin yeri menfisiyle doldurmaktadır. Örneğin namazın sonuna gelmiş birine abdestinin olmadığını, oruç tutana akşamı getiremeyeceğini, zekât vermeye niyetlenene fakirleşeceğini telkin etmesi bunun en tabii göstergesidir. Ayrica namazı bırakmanın sefahate, oruç tutmamanın hırsa, zekât vermemenin ise tamahkârlığa yol açtığı bilinmektedir. İhtiras, hırs ve şehvet gibi dünyevi haletler ise hem bu sistemin telkin ettiği yok ifadesiyle hem de ilahi sevginin perdelenmesiyle ilintilidir. Bu nedenle, ilahi sevgiye giden yolun açılması gerekmektedir. Bu hususta tasavvufçuların da belirttiği gibi terkler üzerinden, farklı bir kanala boyut açılmalıdır.

Sosyal çevre içerisinde var olan insanların din, mezhep, dil ve ırk gibi bir takım farklılıklar üzerinden dışlanmaları sıklıkla karşılaşılan bir durumdur. Yunus Emre bu tür çekişmelerin en temel sebebini, yaratılıştaki birliğin görülememesine bağlamıştır. Ona göre benlik duygusuyla hareket edenler makam, şöhret, mal, mülk, şehvet ve mevki gibi fitratı bozan bir takım perdelenmiş illetlerle ömürlerini geçirmektedir. Başkasına kaptırma, elde edememe, sahip olamama gibi hırslar, başta huzursuzluğa yol açmakta sonrasında ise okyanus genişliğinde olan gönülleri dört köşeli dar bir hapishane suretine çevirmektedir. Yunus Emre birlik makamını işaret ederek, bu makama eremeyenler ikiliğin vermiş olduğu acılara katlanmak mecburiyetinde kalacaklardır telkininde bulunmuştur. Ona göre ikilik bir hastalıktır. Bu hastalıktan kurtulmanın yegâne yolu ise terklerdir (Eğri, 2008, s. 137). Çünkü bu hastalık insanı sevgiden ve hoşgörüden uzaklaştırmakta haset, nefret, öfke ve kin gibi kötü hissiyat girdabına sürüklemektedir. Yunus Emre aşağıdaki beyitte ikiliğin terkine dair bilgilendirmede bulunmuştur;

Ko ikiliği, gel birliğe yet

Bir olan canlar ayrı dölenmez (Toprak, 2006, s. 62).

Karaman Belediyesi, Yunus Emre'nin vefatının 700. yılı anısına, 2 farklı formda pul bastırmıştır. Yayımlanan tasarım örnekleri aşağıda Şekil 4 ve Şekil 5 ile gösterilmiştir. 
Şekil 4. Yunus Emre konulu kişisel pul tasarımı 1, Karaman Belediyesi

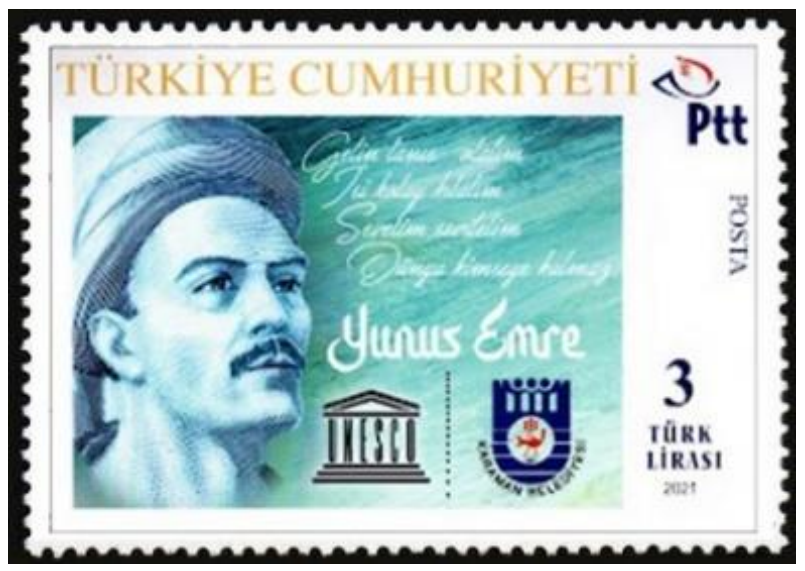

Şekil 5. Yunus Emre konulu kişisel pul tasarımı 2, Karaman Belediyesi

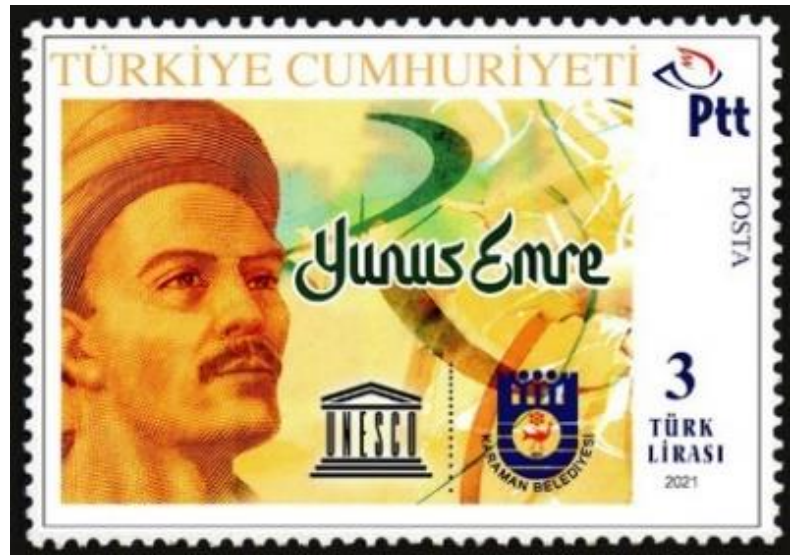

Kaynak: Y1ldırım, 2021: 4.

\section{Yunus Emre'nin Gönül ve Güzellik Anlayışı}

Batı literatüründe tam olarak karşılığı bulunmayan gönül lafzının, doğu dünyasında genellikle akıl kavramıyla karşılaştırılarak varlık gösterdiği görülmektedir. Batı felsefesi, varlık mefhumunu akıl yoluyla açıklamaya çalışırken doğu kültüründe bu anlayış, gönle endeksli seyretmektedir (Akbalik, 2013, s.22).

Yunus Emre gönüllere girmeyi ve oradaki aksayan yönleri onarmayı amaç edinmiş bir Türkmen dervişidir. $\mathrm{O}$ insanın gönlünü Hakkın eviyle özdeşleştirmiştir. Bu nedenle insanın gönlüne, dost ismini vermiştir. Gönül evine misafir olabilmenin önemine değinen Yunus Emre, bunun gerekliliğine farklı birçok dizede ayrıca vurgu yapmıştır. Ona göre misafir olabilmenin yegâne şartı, onarılmaktan geçmektedir. Onarım işlemi için gerekli olan malzeme ise sevgidir. Yunus Emre bütün gönüllerin, nazargâh-1 ilahi olmasını temenni etmektedir. Dolayısıyla o can taşıyan her insanın bu doğrultuda sevk edilmesi gerektiğine kanaat getirmiştir. Hayat mücadelesini şiirlerine yansıtan Yunus Emre aşağıdaki beyitte, varlık gayesine atıfta bulunmuştur (Eğri, 2008, s. 137).

Ben gelmedim dâva için, benim işim sevi için

Dost'un evi gönüllerdir, gönüller yapmağa geldim (Toprak, 2006, s. 150).

Allah (cc) İnsanı yaratırken zatının tecelli edeceği bir aynayı insanın hamuruna yerleştirmiştir. Manevi açidan önem arz eden bu aynadan kastedilen gönüldür. Yunus Emre abdest, namaz, hac ve oruç ibadetinin arka planında var olan latifenin gönül olduğuna işaret 
etmiştir (Sevgi, 2012, s. 101). Gönül yapmanın önemine değinen Yunus Emre, gönül yıkmanın da birçok ulvi değeri ortadan kaldıracağını, sert cümlelerle hususen beyan etmiştir. Hatta âriflik veya âlimlik mertebesine ulaşmış bir zatın bir kez gönül kırması sonucunda, eriştiği makamın ne kendisine ne de bir başkasına hiçbir şekilde fayda sağlamayacağını dile getirmiştir. $O$ gönül yıkmanın, yapılan ibadeti boşa çıkardığına hatta tahkiki bir ibadeti taklidi bir ibadet hükmüne çevirdiğine kanaat getirmiştir. $\mathrm{Bu}$ nedenle gönül yıkanın abdestini gayrimüslimin el yüz yıkamasına, görülen hac vazifesini ise keyfi olarak gerçekleştirilen bir seyahate benzetmiştir. İnsan topluluğunu yetmiş iki millet olarak niteleyen Yunus Emre, gönül yapmanın önemini ve namaz kılan Müslümanın farkını, aşağıdaki dizelerde sarih bir ifadeyle ortaya koymuştur (Eğri, 2008, s. 140; Sevgi, 2012, s. 101).

Bir gez gönül yıktın ise, kıldı̆̆ın namaz değil

Yetmiş iki millet dahi, elin yüzün yumaz değil

Bir gönül yaptın ise, er eteğin tuttun ise

Bir gez hayr ettin ise, birine bin az değil (Toprak, 2006, s. 176).

Şeyh Sadi, güzellik kavramını açıklarken şöyle bir örneklemede bulunmuştur: Emsalsiz bir güzelliğe sahip olan Hz. Yusuf'a inkâr nazarıla bakan bir göz, muhakkak ki onu çirkin görür. Yunus Emre de bu konuda düşüncelerini aktarırken benzer ifadeler kullanmaktadır. Ona göre mevcudata, sevgi dolu gözlerle bakılmalıdır (Sevgi, 2012, s. 101). Çünkü Allah (cc) her şeyi en güzel şekilde yaratmıştır. Bu nedenle Allah'ın (cc) yarattığı bütün insanlara bir gözle bakmak gerekir. Bunun dışına çıkanlar, zahirde ilim ehli olarak gözükseler de hakikatte böyle değillerdir. Yunus Emre aşağıdaki beyitte, ayrımcılığa meyletmenin ne denli yanlış bir davranış olduğunu ortaya koymuştur.

\section{Yetmiş iki millete bir gözle bakmayan}

Halka müderris olsa hakikatte âsîdir (Tatc1, 1997, s. 46).

Şekil 6. Yunus Emre sevgiye davet ve gönül birlikteliği konulu tasarım

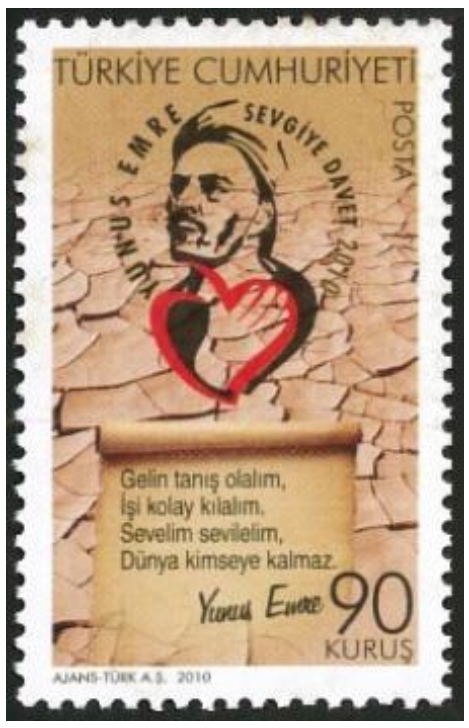

Kaynak: Araştırmacının arşivinden taratılarak elde edilmiştir.

\section{Yunus Emre'nin Sevgi ve Hoşgörü Anlayışı}

Anadolu'nun dini ve sosyal yapılanmasında önemli katkıları olan Mevlana ve Yunus Emre beraberlik ve hoşgörü telkiniyle halkı erdemli olmaya davet etti. O dönemde halkı meşgul eden çeşitli problemler bulunmaktaydı. Moğol İstilası, taht mücadelesi ve Babai İsyanı bu olayların başlıca nedenleri arasında yer almaktaydı. Halk, siyasi güçlüklerin yanı sıra ekonomik 
ve psikolojik sıkıntıları da aşmak zorundaydı (Öztürk ve Celep, 2014, s. 78-80). Bundan önceki dönemde Anadolu'da refah ortamı tesis edilmişti. Bunda belirleyici olan Selçukluların uyguladıkları politikalardı. Dirlik ortamı, yalnızca Müslümanlar için değil aynı zamanda bu bölgede yaşayan gayrimüslimler için de teminat hükmündeydi. Hatta bu sükûnet ortamı, olas1 göçler için uygun bir zemin oluşturdu. Bu nedenle siyasi istikrarın kırılganlık gösterdiği coğrafyalardan Anadolu'ya doğru ciddi bir göç akını başladı. Göç hareketindeki sürekli artış, öncelikle ekonomiyi çıkmaza soktu. Sonrasında yaşanan dini, kültürel ve demografik uyuşmazlık kısa zamanda siyasi kargaşaya dönüştü ve istikrarın bozulmasına neden oldu (Kaval, 2013, s. 101-102). Yunus Emre'nin yaşadığı dönemde Anadolu coğrafyasında çok sayıda etnik ve dini unsur mevcuttu. Bu dönemde hem Ermenilerin hem de Hristiyanlığ benimseyenlerin inandıkları ve sevdikleri peygamberleri bulunmaktaydı. Farklı inançlara mensup olanların diğer bir toplumun peygamberini kabul etmemesi, o dönemde gündemi en çok meşgul eden konulardan biriydi. Herkesten farklı düşünen Yunus Emre Kur'an-1 Kerim'de ismi zikredilen bütün peygamberlere inandığını ve bunun da Müslümanlığın bir gereği olduğunu ilan etti. Bu ilan, farklı inanç grupları tarafından barış çağrısı olarak algılandı. Kısa sürede karşılık bulan bu çağrı, sonraki süreçte Yunus Emre'ye duyulan sevgi hissini giderek arttırdı (Eğri, 2008, s. 139). Bu nedenle yerli halkın bir kısmı, bu hoşgörü ortamı içerisinde herhangi bir zorlamaya maruz kalmadan İslamiyet'i kabul etti. Hoşgörülü davranmayı telkin eden Yunus Emre aşağıdaki dizelerle ilahilere güfte oluşturdu ve sevginin önemini nağmelere dizdi.

Gök yüzünde isa ile, Tur dă̆ında Musa ile

Elimdeki asâ ile, çağırayım Mevlâm seni

Derdi öküş Eyyup ile, gözü yaşlı Yakup ile

Ol Muhammed-i mahbub ile çağırayım Mevlâm seni (Toprak, 2006, s. 73).

İnsan sevgisinin temelini Allah (cc) sevgisine dayandıran Yunus Emre'nin bu düşüncesi, Allah'ın (cc) insanları, yeryüzünde kendi esmalarını taşımakla onurlandırılmış varlıklar olarak görmesinden ileri gelmektedir. Dolayısıyla gerçek anlamda Hakkı sevmenin, cümle âlemi kardeş kabul etmekle eşdeğer olduğu vurgulanmıştır. Çünkü gerçek seven, herhangi bir ayrım gözetmeksizin herkese yardım eder, kalp kırmaktan kaçınır hatta kötü bir davranışa iyilikle karşıllı verir (Demirci, 2008, s. 141).

Farsça kökenli bir sözcük olan hûş sözcügüyle, görmek fiilinden gelen görü ekinin bir araya gelmesiyle hoşgörü kavramı oluşmuştur. Bu kavram iyi, güzel, ilgi uyandıran, okşayan, beğenilen ve tatlı gibi anlamlar içermektedir. Hoşgörü kavramı, karşıt inançlara ve düşüncelere karşı olabildiği kadar anlayışlı olmayı ve esnek davranmayı telkin etmektedir. Bu nedenle Yunus Emre dizelerinde sıklıkla sevgiyi ve hoşgörüyü telkin eden ifadeler kullanmıştır. Hoşgörü kavramının, insanın fitratıyla bütünleşmesi gerektiğine inanan Yunus Emre, aşağıdaki dizelerde bu durumu şöyle özetlemiştir (Aslan, 2001, s. 1-4).

\section{Elif okuduk ötürü}

Pazar eyledik götürü

Yaratılanı hoş gör

Yaratan'dan ötürü (Tatc1, 1997, s.10).

Hoşgörülü olmayı ilke edinen Yunus Emre'nin bir tek düşmanı vardır. O da nefsidir. Kavgadan uzak bir yaşantıyı yeğleyen Yunus Emre hevâ ve heveslerinin arkasından koşan nefsiyle sürekli bir savaş halindedir (Eğri, 2008, s. 138-139). Ona göre insan-1 kâmil mertebesine erişebilmek için insanın başta kendi nefsini kırması gerekmektedir. Çünkü kendini pergel olarak merkeze koyan nefis, etrafı karartır ve benlik duygusunu hâkim kılar. Bunun sonucunda da kin ve nefret duygusu canlı kalır. Bu nedenle Yunus Emre, nefisi besleyen 
yolların kesilmesi gerektiğine inanmaktadır. Aşağıdaki dizelerde bu konu daha iyi bir biçimde özetlenmiştir;

\section{Adımız miskindir bizim,}

Düşmanımız kindir bizim,

Biz kimseye kin tutmayız,

Kamu âlem birdir bize (Tatc1, 1997, s. 426).

Bütün kâinatı belirli bir nizam içerisinde yaradan Allah (cc) mevcudatta var ettiği hiçbir şeyi de boşuna halk etmemiştir. Arştan ferşe kadar halk edilen her bir unsurun asli bir vazifesi vardır. Her mevcudat, istidadı kabiliyetinde üslendiği vazifesini ifa etmek için gayret sarf eder. $\mathrm{Bu}$ nedenle başkasının doğrusu bize yanlış gelebilir. Hatta biz bu yanlış anlamayla başkasının yaşam hakkına kastedebiliriz. Dolayısıyla Merkez Efendinin dediği gibi: Allah (cc) bana kâinatı yeniden yarat diye emir verse idi ben bu kadar muazzam ve kusursuz yaratılmış olan hiçbir şeye dokunmaz, bütün mevcudatı yine merkezinde bırakırdım demiştir. Dolayısıyla yaratılmış olan canlı ve cansız bütün mevcudatta Allah'ın (cc) esmaları tecelli etmektedir. Bu nedenle bütün yaratılmışlara sevgi ve hoşgörü nazarıyla bakmalıdır. Sevgi ve hoşgörünün hâkim olduğu coğrafyalarda egemen unsur, her zaman barış olmuştur.

Şekil 7. Yunus Emre Sevgi Y11 1991

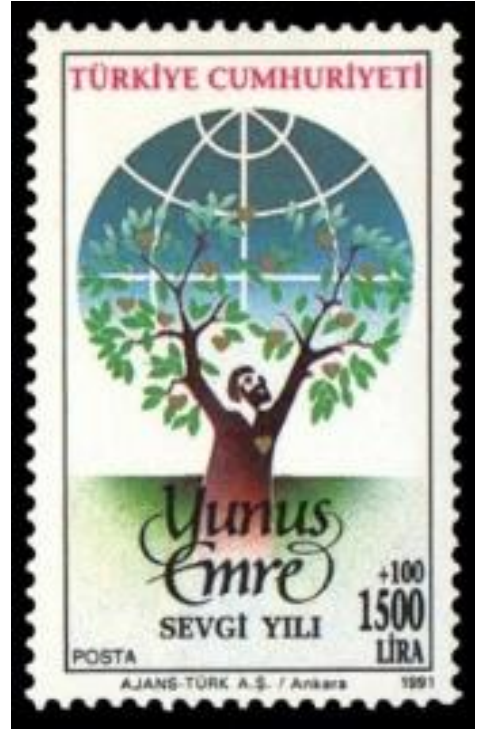

Şekil 8. Yunus Emre Sevgi Y1l1 1991

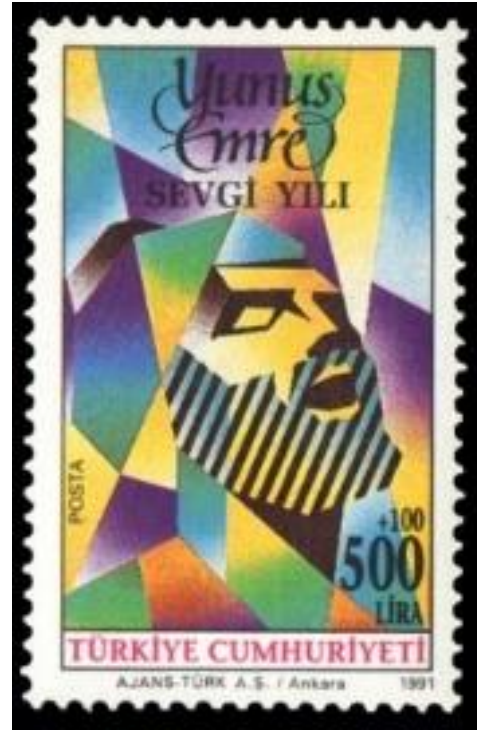

Kaynak: Aycil, 2021: 339; Yıldırım, 2021: 8.

Şekil 9. Hoşgörü ve sevgi konulu tasarım

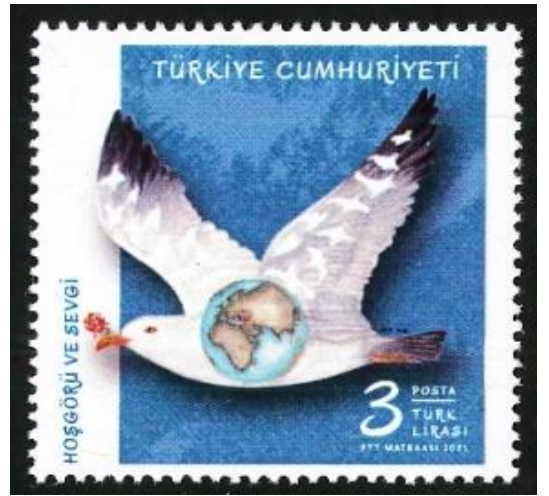

Kaynak: Araştırmacının arşivinden taratılarak elde edilmiştir. 


\section{Yunus Emre'nin Kabri Nerede?}

Anadolu'nun birçok yerinde Yunus Emre'ye ait olduğu rivayet edilen makam, mezar ve türbe bulunmaktadır. Bu yapılar, nispeten geniş bir coğrafyaya yayılmış vaziyettedir. Makam olarak anılan yerler; Karaman'da Kiriş̧̧i Baba Camii, Limni Adasında mezar veya makam, Tire'de camii ve dergâh olarak kayıtlanmıştır. Mezar yapıları ise Bursa, Bolu, Kırşehir, Manisa ve Sivas vilayetlerinin yanı sıra Keçiborlu, Sandıklı ve Ünye ilçelerinde yer almaktadır. Ayrıca Eskişehir ile Afyonkarahisar arasındaki demiryolu hattının Döğer mevkiinde Emre Sultan adıyla bilinen bir mezar yapısı da mevcuttur. Türbeler içerisindeki en bilindik yapı Eskişehir'in Mihalıççı İlçesinin Sarıköy'ünde bulunan anıt mezardır. Bundan başka Manisa’nın Kula ilçesi ile Erzurum'un Tuzcu köyü, Aksaray'ın ise Taptuk köyündeki bir tepenin üzerinde iki türbe ve mezar yer almaktadır. Her üç yerleşim yerindeki bu mezarların Yunus Emre ve Taptuk Emre’ye ait olduğu rivayet edilmektedir. Resmi kayıtlarda ise sadece 4 yeri işaret eden belgeler mevcuttur. Bunlar; Bursa, Eskişehir, Karaman ve Tire'dir (Benazus, 2021, s. 65-66; Güngör, 1991, s. 35). Ancak Zülfikâr Çelebiye ait defter ile Vilayetname birlikte değerlendirildiğinde Sarıköy'ün Kızılırmak kenarında bir karye Sivrihisar'ın ise bugünkü Aksaray vilayetine bağlı bir yerleşim yeri olduğu bilgisi ortaya çıkmaktadır (Topal, 2017, s. 62). Yunus Emre, çağların ötesine seslenen önemli bir şahsiyettir. Onun ettiği kelamlarda birçok manalar mevcuttur. $\mathrm{Bu}$ nedenle onun her devirde efradı bulunmaktadır. $\mathrm{O}$ aşağıda yer verilen beyitiyle, zamanın ötesine mesajını vermiştir.

\section{Yunus senin sözlerin, mânadir bilenlere}

Söylenirse sözlerin, devr ü zaman içinde (Toprak, 2006, s. 179).

Şekil 10. Yunus Emre Külliyesi ve Türbesi, Mihalıççık, Eskişehir

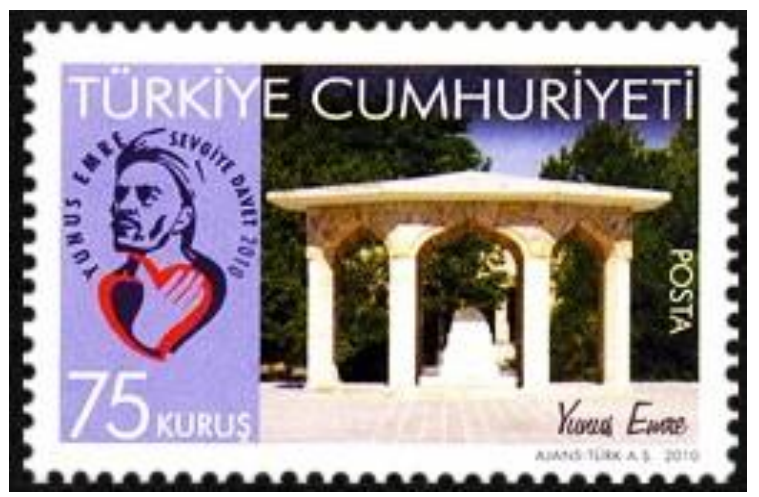

Kaynak: Araştırmacının arşivinden taratılarak elde edilmiştir.

\section{Tartışma ve Sonuç}

Yunus Emre Anadolu'da saygı gören ve sevilen bir şahsiyettir. O tasavvufi şahsiyetinin yanı sıra edebi ve felsefi yönüyle de gönüllerde yer edinmiştir. Gerek doğum yeri gerekse mezarı konusunda hala çözümlenememiş ihtilaflı beyanlar bulunmaktadır. Onun bu denli özümsenen bir şahsiyet olmasında, halkın sevgisini kazanmış olduğu gerçeği yatmaktadır. Zaten nereli olduğu ve nerede yattığı konusundaki ihtilaflı beyanlar aslında ona karşı duyulan sevginin büyüklüğünden kaynaklanmaktadır. Çünkü herkes Yunus Emre'yle kendisini özdeşleştirmek istemektedir. Bu nedenle memleket ve ata toprağ 1 üzerinden manevi bir iklim oluşturulmaya çalışılmaktadır.

Sevgi ve hoşgörü ilkesi üzerinden duygu dünyamıza hitap eden Yunus Emre, farklı birçok yönüyle, bu coğrafyada yaşamış olan milletleri etkilemiştir. Anadolu'nun tekrar huzurlu bir yurt ortamına kavuşmasında, onun katkıları yadsınamaz. $\mathrm{O}$ öğretileriyle insanların manevi dünyasına hitap eden örnek bir şahsiyettir. Manevi açıdan oluşan boşluğu aşk, insan sevgisi ve hoşgörüyle doldurmaya çalışan Yunus Emre, bu sayede anlayışın ve kalıcı barışın temellerini de 
atmıştır. Onun sözleri Anadolu'da yaşayan milletleri bir araya getiren ortak bir barış çağrısıdır. $\mathrm{Bu}$ nedenle Yunus Emre'nin herhangi bir şiirinde tasavvuf, sevgi, aşk, hoşgörü ve barış manalarını çıkarmak mümkündür.

Bazı kaynaklarda Yunus Emre'nin okuryazar olmadığı belirtilmektedir. Hâlbuki bugüne kadar geçen sürede ona ait olduğu tespit edilen birçok eserine rastlanmıştır. İki farklı eserinin dışında sayısız şiirleri de bulunmaktadır. Yakın zamanda, farklı ülke arşivlerinde de ona ait olan bazı eserler ortaya çıkmıştır. Onun ümmi olup olmadığından ziyade Türk edebiyatına ve düşünce sistemine sunduğu katkılara bakılmalıdır. Çünkü onun eserlerine muhatap olan her birey, kendi düşünce yapısını inşa etmektedir. Bu yapılanma süreci ise bireyden bireye farklılık göstermektedir. Dolayısıyla her birey onun eserlerinden istidadı ölçüsünde hissesini almaktadır.

Yunus Emre konulu pul tasarımları genellikle sade ve anlaşılır ögeler içermektedir. $\mathrm{Bu}$ tasarımlarda üzerinde en çok durulan konular ise sevgiye davet, hoşgörü, birliktelik çağrısı, barış ve Türk dili vurgusudur. Yunus Emre'nin sevgi anlayışının mevcut tasarımlara kalp sembolüyle yansıtıldığını söylemek mümkündür. Bu nedenle figürlerde genellikle kalp simgesi, derviş selamı, sevgi içerikli beyitler ve Türkçe ifadeler kullanılmıştır.

Yunus Emre'nin eserleri, ilahi bir özlemle yazılmış derin manalar içermektedir. Onun hissettikleri onunla sınırlı kalmamış ve bütün insanlığa mal olmuştur. Yıllar geçmesine rağmen realite değişmemiştir. Günümüzde hala Yunus Emre gibi değerlere ihtiyaç duyulmaktadır.

\section{Kaynakça}

Akbalık, E. (2013). Yunus Emre'nin şiirlerinde gönül imgesi. Uluslararası Sosyal Araştırmalar Dergisi, 6(26), 20-28.

Aslan, Ö. (2001). Hoşgörü ve tolerans kavramlarına etimolojik açıdan bir yaklaşım. Cumhuriyet Üniversitesi İlahiyat Fakültesi Dergisi, 5(2), 357-380.

Aycil, S. (2021). Posta pullarının işlevsel yönü ve menkul kıymet olarak değerlendirilmesi. Pamukkale Üniversitesi Sosyal Bilimler Enstitüsü Dergisi, 47, 333-357.

Benazus, H. (2021). Yunus Emre. İstanbul: İleri Yayınları.

Demirci, M. (2008). Yûnus'ta hak ve halk sevgisi. İstanbul: H Yayınları.

Eğri, O. (2008). İslâm tasavvufu ve hoşgörü: Hoca Ahmet Yesevî, Hacı Bektaş Veli, Yunus Emre örnekleri ve diğer dinlerdeki paralelleri. 38. ICANAS (Uluslararası Asya ve Kuzey Afrika Çalışmaları Kongresi, Atatürk Kültür, Dil ve Tarih Yüksek Kurumu, Ankara.

Ekici, K. (2005). Anadolu Selçukluları'nda Türkmen isyanlarının nedenlerine ilişkin tespitler. SDÜ Fen Edebiyat Fakültesi Sosyal Bilimler Dergisi, (13), 89-102.

Güngör, İ. H. (1991). Devlet arşivlerinde Yunus Emre ile ilgili belgelerin ortaya koyduğu gerçekler. Vakıf Haftası Dergisi, 8, 35-81.

Güven Bezaz, Y. (2006). Geçmişten günümüze haberleşme ve PTT tarihi. Ankara: Türkiye Haber-İş Sendikası Yayınları.

Kaplan, K. (2018). Yunus Emre'nin şiirlerinde insan ve doğa. Erzincan Üniversitesi Sosyal Bilimler Enstitüsü Dergisi, XI(1), 155-166.

Kaval, M. (2013). Yunus Emre ve Mevlâna'nın eserlerinde insan ve tekâmülü. Uşak Üniversitesi Sosyal Bilimler Dergisi, 6(2), 101-122.

Keleş, B. (2018). Baba İshak isyanının Anadolu Selçuklu tarihindeki yeri ve önemi. Fırat Üniversitesi Illahiyat Fakültesi Dergisi, 23(1), 73-91. 
Koca, S. (2015). Türkiye Selçuklu tarihinin akışını değiştiren ve Anadolu'nun kaderini belirleyen savaş: Kösedağ bozgunu. Selçuk Üniversitesi Türkiyat Araştırmaları Dergisi , (37), 35-84. doi: 10.21563/sutad.187067

Koç, R. ve Tanhan, F. (2010). Yunus Emre’nin şiirlerinde değerler sistemi. Eskişehir Valiliği X. Uluslararası Yunus Emre Sergi ve Bilgi Şöleni, Osmangazi Üniversitesi, Eskişehir.

Merriam, S. B. (2013). Nitel araştırma: desen ve uygulama için bir rehber (S. Turan, Çev.). Ankara: Nobel Yayıncilık.

Öztürk, E. ve Celep, H. (2014). Selçuklu Anadolu'sunda sûfi ahlâkı ve sosyal barış. Avrasya Uluslararası Araştırmalar Dergisi, 5(5), 74-90. https://doi.org/10.33692/avrasyad.175260

Pür, İ. (2021). Yûnus Emre anısına Türk ve Türk Dünyası araştırmaları-IX. Y. E. Tansü (Ed), Yûnus Emre' nin Dünya ve Ahiret İlişkisinin Psikolojik Açıdan İncelenmesi içinde (ss. 1740). Ankara: İksad Yay.

Sevgi, A. (2021). Yunus Emre'de insan sevgisinin evrensel niteliği üzerine. Turkish Studies, 7(1), 99-103. doi: http://dx.doi.org/10.7827/TurkishStudies.3182

Tatcı, M. (1997). Yûnus Emre Divânı II. İstanbul: Milli Eğitim Bakanlığı Yayınları.

Topal, N. (2017). Yunus Emre'nin Aksaray'daki mezarı üzerine düşünceler. O. K. Tavukçu (Ed), Yûnus Emre kitabı içinde (ss. 55-82). Ankara: Akçağ Yayınevi.

Toprak, B. (2006). Yunus Emre Divanı. İstanbul: Odunpazarı Belediyesi Yayınları.

Ülken, H. Z. (2001). Bilgi ve değer, İstanbul: Ülken Yayınları.

Wach, E. ve Ward, R. (2013). Learning about qualitative document analysis. https://opendocs.ids.ac.uk/opendocs/handle/20.500.12413/2989 (Erişim tarihi: 05.06.2021).

Yavuz, K. (2017). Yunus Emre'nin yaşadığı zamanda Türk edebiyatına genel bir bakış. O. K. Tavukçu (Ed), Yûnus Emre kitabı içinde (ss. 25-36). Ankara: Akçağ Yayınevi.

Yıldırım, A. ve Şimşek, H. (2008). Sosyal bilimlerde nitel araştırma yöntemleri. Ankara: Seçkin Yayıncilik.

Yıldırım, Y. (2012). Yunus Emre belgeler, bilgiler, Karaman: Karaman Valiliği-Karaman Belediyesi Yayınları.

URL-1: $\quad$ https://www.eskisehirekspres.net/mihaliccik/yunus-emre-icin-mihaliccik-ta-pulbastirildi-h41391.html (Erişim tarihi: 06.07.2021).

ETIKK ve BİLIMSEL İLKELER SORUMLULUK BEYANI

$\mathrm{Bu}$ çalışmanın tüm hazırlanma süreçlerinde etik kurallara ve bilimsel atıf gösterme ilkelerine riayet edildiğini yazar(lar) beyan eder. Aksi bir durumun tespiti halinde Afyon Kocatepe Üniversitesi Sosyal Bilimler Dergisi'nin hiçbir sorumluluğu olmayıp, tüm sorumluluk makale yazarlarına aittir. 